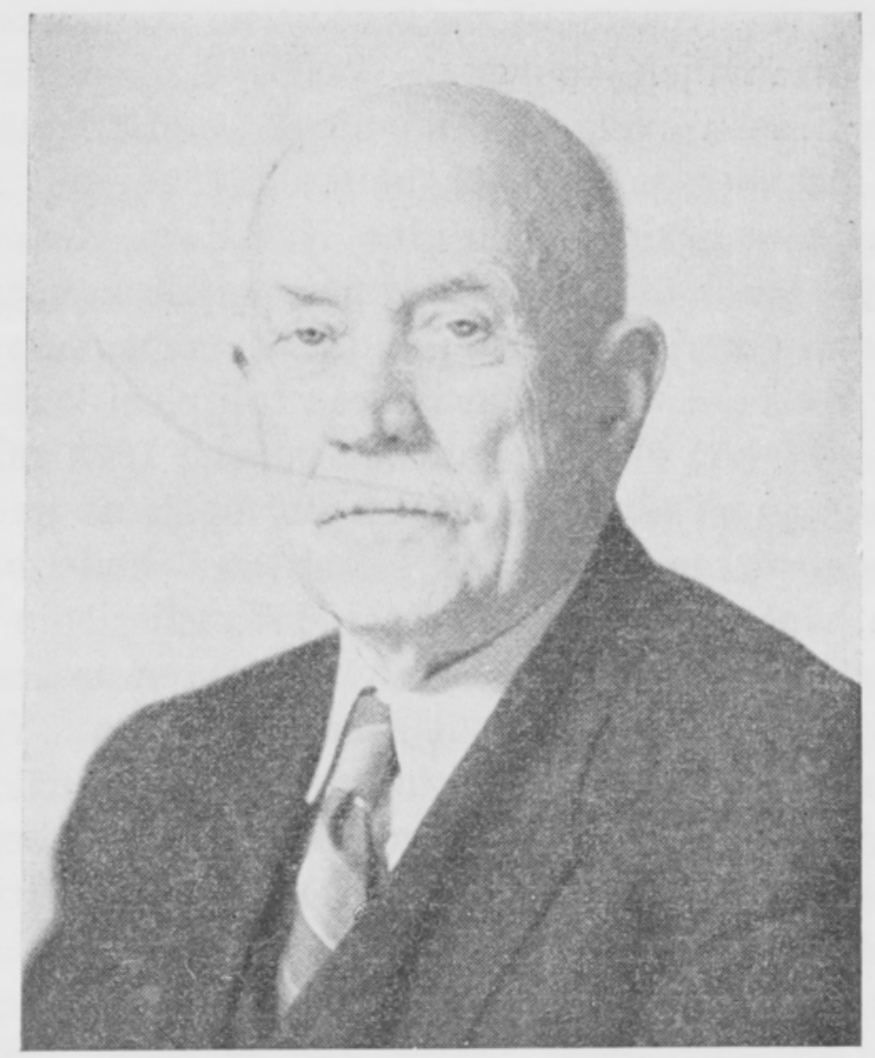

\title{
GUSTAF ADOLF BREDENBERG
}

* 10.8. $1865-\dagger 21.2 .1955$

Täysinpalvellut meijeriopin professori, maamme maitotalouden opetus- ja tutkimustoiminnan uranuurtajia, Gustaf Adolf Bredenberg kuoli helmikuun 21 päivänä 89:1lä ikävuodellaan. Hän oli syntynyt 10. 8. 1865 Bromarvissa, merikapteeni, laivanvarustaja, tilanomistaja Gustaf Samuel Bredenbergin poikana. Ylioppilaaksi tuli hän 1886 Helsingin ruotsalaisesta normaalilyseosta ja valmistui agronomiksi Mustialasta 1890. Opintojaan hän jatkoi Helsingin yliopistossa suorittaen 1891 fil.kandidaatin tutkinnon, pääaineena kemia. Kotimaassa suoritettuja tutkintoja hän täydensi ulkomailla opiskelemalla, mistä tuloksena hän suoritti tutkinnon meijeri- ja kotieläinopissa Kööpenhaminan Landbohøjskolessa. Tämän lisäksi hän suoritti bakteriologisia kursseja Kööpenhaminan yliopistossa. Kielin koelaitoksessa ja lisäksi tri Orla-Jensen'in luona, tämän sittemmin maitotalouden bakteriologiassa ratkaisevaa laatua olevan tutkimustyön tehneen, suuren tutkijahahmon oppilaana.

Korkeakouluopinnoista on edelleen merkillepantavaa fil.lisensiaatin tutkinto, jonka Bredenberg suoritti 1912, pääaineena meijerioppi. Samana vuonna hän vielä väitteli tohtoriksi väitöskirjalla: "Beiträge zur Kenntnis der Hüllen der Milchfettkügelchen.» Väitöskirjaan sisältyvät kokeelliset työt hän oli tehnyt Berliinin maatalouskorkeakoulun eläinfysiologisessa instituutissa. 
Agronomiksi valmistuttuaan Bredenberg otti vastaan ensimmäisen toimipaikkansa Harjun maanviljelyskoulussa. Tästä alkoi pitkäaikainen tulosrikas elämäntyö opetustoiminnan alalla. Johtajana ja ammattiaineiden opettajana oli hän Vestankvarnin maamies- ja emäntäkoulussa v. 1894-97. Mustialassa meijeriopin vt. opettajana ja meijeriopin lehtorina Kurkijoen ylemmässä maanviljelyskoulussa v. 1897-98, jonka viimeksi mainitun oppilaitoksen meijerikoulun johtajana ja ensimmäisenä opettajana hän oli neljättä vuotta, siirtyen 1901 Mustialan opiston meijeriopin opettajaksi. Tämän jälkeen tuli pieni keskeytys Bredenbergin opettajatoimintaan, sillä hän oli perustamassa vuonna 1903 valtion vointarkastuslaboratoriota Hankoon ja oli tämän laitoksen ensimmäisenä johtajana v:teen 1907. Meijeriopin apulaisen virkaa Helsingin yliopistossa hoiti hän virkaatekevänä v. 1907-13, jolloin hänet nimitettiin vakinaiseksi meijeriopin adjunktin virkaan. Tämä virka muutettiin sitten 1921 kiinteän ylimääräisen professorin viraksi, jonka ensimmäiseksi haltijaksi Bredenberg tuli samana vuonna. Yliopistossa Bredenberg toimi opettajana näin ollen lähes kolmekymmentä vuotta. Tänä aikana hän loi korkeimmassa meijeriopetuksessa ne suuntaviivat, joita tietyssä mitassa edelleenkin noudatetaan. Hänen yliopistollisen toimintansa aktiivisin puoli olikin juuri opetuksessa, jossa hän omaperäisellä, melkeinpä patriarkaalisella tavalla kasvatti varsin huomattavan oppilasjoukon maa- ja meijeritaloutemme palvelukseen.

Hänen tärkeimmistä tutkimuksistaan muodostaa olennaisen osan aihepiiri, joka sisältyi hänen edellämainittuun väitöskirjaansa. Tämä käsitteli kysymystä, jonka selvittämisen jo silloiset tutkijat oivalsivat olevan monessakin suhteessa tärkeän. Meijeritieteen kehitystä seurattaessa voidaankin sanoa maidon rasvapallosten kelmulimaongelman aina meidän päiviimme asti toistuvasti tulleen tutkimuksen piiriin, koska tiedot membraaneista antavat ikäänkuin avaimen rasvan kolloidikemiallisten ominaisuuksien ymmärtämiseksi maidossa ja maitotuotteissa. Kuinka keskeistä osaa maitorasvan membraanikompleksi tässä suhteessa merkitsee, ilmenee mm. siitä, että ne monet teoriat, joita aikojen kuluessa kerman kirnuuntumisesta on esitetty, käsittelevät kaikki myös kysymystä rasvapallosten membraanien osuudesta tähän ilmiöön. Kun Bredenberg ryhtyi tätä asiaa selvittämään, ei suinkaan vielä yksimielisesti hyväksytty edes tällaisen membraanin olemassaoloa. Niinpä Bredenberg väitöskirjassaan toteaakin, että tutkijat voidaan jakaa kahteen leiriin kysymyksessä: "Sind die Fettkügelchen der Milch von einer Hülle umgeben, oder nicht.» Bredenberg lähtee kuitenkin siitä, että tämä membraanikerros on olemassa ja tulee itseasiassa hyvin moderniin lopputulokseen, koska hän toteaa tämän muodostuvan kahdesta eri substanssista, joista toinen olisi proteiini. Fosfatideja, jotka nykyisen käsityksen mukaan ovat membraanien perusosana ei Bredenberg, eikä muutkaan senaikaiset tutkijat vielä todenneet. Tätä samaa kysymystä Bredenberg tutki vielä väitöskirjatyön jälkeenkin ja julkaisi tutkimuksen: „Studien über die Fettkügelchen in der Kuhmilch».

Bredenbergin muista tärkeimmistä tutkimuksista on lähinnä mainittava suomalaisen vientivoin vesipitoisuutta käsittelevä työ: »Studien über den Wassergehalt der finnischen Exportbutter». 
Kun Bredenberg tuli yliopistoon, oli hänen opetusaineeseen luotava perusta alusta pitäen. Maitotalous ja meijeritiede elivät silloin murroskautta. Empirismin aikakausi oli väistymässä ja eksaktisiin luonnontieteisiin perustuvat tutkimusmenetelmät sekä tältä pohjalta lähtevät käytännön sovellutukset astuivat yhä yleisimmin tilalle. Näiden uusien prinsiippien juurruttaminen opetukseen merkitsi silloisissa olosuhteissa arvaamattoman paljon ja tällä pohjalla koulutetut agronomit voivat käytännön elämän palvelukseen siirtää uusien menettelytapojen hedelmällisen vaikutuksen.

Mutta Bredenberg ei tyytynyt vain yliopistossa johtamaan kehitystä, vaan häntä tarvittiin myös suoranaisesti käytännön elämän edistämistyöhön yliopiston ulkopuolella. Tämä puoli Bredenbergin elämäntyöstä onkin kunnioitettavan laaja ja monipuolinen. Hänellä oli se kaukonäköinen oivallus, että vain sikäli tieteen saavutuksilla maatalouden alalla on merkitystä, mikäli ne voidaan sovelluttaa käytännöllisen elämän palvelukseen. Tässä tulkoon mainituksi vain eräitä hänen monitahoisen toimintansa kohteista.

Bredenberg oli vuodesta 1916 lähtien puheenjohtajana Suomen Juustonvalmistajayhdistyksessä kuolemaansa saakka. Tätä tehtävää hän hoiti erittäin suurella antaumuksella ja se oli tullut hänelle niin läheiseksi, että hän aivan viime vuosiin asti osallistui yhdistyksen vuosittain järjestämiin juustomeijereiden tarkastuksiin. Hänen aloitteestaan perustettiin 1923 Södra Finlands meijeriförbund ja hän toimi sen puheenjohtajana 20 vuotta. 1924 hän oli Maataloustieteellisen seuran johtokunnan jäsen. Kansainvälisen Meijeriliiton (Fédération Internationale de Laiterie) Suomen kansallisen komitean jäsenenä hän oli vuodesta 1932. Bredenberg oli vakituinen jäsen ISK:ssa ja LSK:ssa, Suomen maatalousakatemiassa, Keskusmetsäseurassa, Pellervo-Seurassa ja Suomen sianjalostusyhdistyksessä. Huomattavista ansioistaan hänet oli kutsuttu $\mathrm{mm}$. seuraavien seurojen ja yhdistysten kunniajäseneksi: Meijeritieteellinen seura, Södra Finlands meijeriförbund, Suomen maataloustieteellinen seura, Agronomien yhdistys ja Svenska studenters agroforstförening.

Bredenberg oli varsin monipuolisesti käytetty voima maa- ja meijeritalouden kehittämistyössä. Erityisesti on vielä mainittava, että hän oli esitelmöitsijänä ja tuotteiden arvostelijana useiden vuosien ajan niissä voi- ja juustonäyttelyissä, joita meijeriliitot järjestivät. Käytännön elämän kanssa näin kosketuksiin joutuessaan hän varmaan samalla sai itselleen jatkuvasti uusia herätteitä opetustyöhönsä. Hän voi myös läheltä seurata oppilaittensa toimintaa, senjälkeen kun he olivat yliopiston jättäneet. Näiden menestyminen olikin aina hänen sydäntään lähellä ja hän oli heille isällinen neuvonantaja vaikeuksien sattuessa.

Aivan erityisen piirteen Bredenbergin elämänkuvalle antaakin juuri hänen väsymätön, uhrautuva työnsä opiskelevan nuorison hyväksi. Tämä ilmeni ehkä näkyvimmin Agro-forstföreningen'in toiminnassa, jossa Bredenberg oli mukana perustamisesta lähtien ja pitkälti vielä sen jälkeen kun hän jätti yliopiston. Viimeisen kerran oli hän yhdistyksen kókouksessa vuonna 1954.

Harvoille toiminnan ihmisille on suotu niin pitkäaikainen, rikas elämä kuin professöri Bredenbergille. Kun otetaan huomioon, että hän tietyssä määrässä oli 
aktiivisesti mukana aivan viimeisiin elinvuosiinsa asti, voi hän näin ollen seurata erityisesti meijeritaloutemme kehitystä seitsemättä vuosikymmentä. Toisin sanoen hän on elänyt suurimman osan siitä ajasta, jolloin järjestettyä meijeritoimintaa on maassamme ollut. Hän oli perusteellisesti valmentautunut ottamaan vastaan ne tärkeät tehtävät, jotka hänen vastuulleen tulivat, kun maa- ja meijeritaloutemme nousukausi vuosisadan vaihteessa alkoi. Hänen työnsä tulokset ovat löydettävissä varsin monelta taholta, mutta huomattavinta osaa, henkisen kylvön rikkautta, on meidän nykypolven enää mahdoton edes osapuilleen mitata. Professori Bredenbergin olemuksessa oli ainutlaatuista hengen vitaliteettia, sopusointuisesti yhtyneenä lujaan fyysilliseen kestävyyteen, joka teki hänestä meijeritaloutemme todellisen "grand old man'in".

Matti Hietaranta. 


\title{
PROFESSOR G. A. BREDENBERG
}

\author{
10. $8.1865-21.2 .1955$
}

Am 21 Februar 1955 verschied in seinem Heim in Helsinki Professor Emeritus Gustaf Adolf Bredenberg in Alter von 89 Jahren. Durch seinen Tod verlor die finnische Milchwirtschaft einen ihrer Senioren.

Professor Bredenberg wurde am 10 August 1865 in Bromarv geboren. Sein Interesse lenkte sich schon früh auf die Landwirtschaft und im Jahre 1890 legte er am Landwirtschaftlichen Institut in Mustiala sein Agronomexamen ab. Sein wissenschaftliches Interesse veranlasste ihn jedoch seine Studien an der Universität in Helsinki fortzusetzen und 1891 errang er den Grad eines Kandidaten der Philosophie. Darauf vervollständigte er sein Wissen durch Studien im Ausland, vor allem trieb es ihn nach Kopenhagen, wo damals der erste Gelehrte der Milchbakteriologie Orla-Jensen wirkte. Im Jahre 1892 legte Bredenberg an der Landbohøjskole in Kopenhagen seine Prüfung in Molkerei- und Haustierlehre ab, worauf er nach weiteren Studien an den Universitäten in Kiel und Berlin und in der Schweiz für seine Lebensaufgabe in der Heimat gerüstet war.

Professor Bredenbergs Lebenswerk war reich und von langer Dauer. Seine Hauptaufgabe sah er in der Erziehung von kompetenten Fachleuten für die finnische Land- und Milchwirtschaft. Seine Lauftbahn als Lehrer begann er an der Landwirtschaftlichen Schule in Harju, danach wirkte er 1894-97 in Vestankvarn an der Landwirtschaftlichen Schule, sowie 1897-1903 als Lehrer der Molkereilehre an den Schulen in Kurkijoki und Mustiala. Die einzige Unterbrechung in Bredenbergs Lehrertätigkeit waren die Jahre 1903—07, während denen er das von ihm gegründete Laboratorium der Staatlichen Butterkontrollanstalt in Hanko leitete. Im Jahre 1907 beginnt Bredenbergs Universitätslaufbahn als Lehrer und ab 1921 als erster Professor der Molkereilehre, die er bis seiner Pensionierung in Jahre 1934 fortsetzen sollte und die unter seinen Schülern reiche Frucht brachte.

Bredenbergs wissenschaftliches Schaffen beginnt mit seiner Doktorarbeit, die in die Zeit fiel, in der der Durchbruch der exakten Naturwissenschaften auch auf dem Gebiet der Land- und Milchwirtschaft vor sich ging. Seine Arbeit: „Beiträge zur Kenntnis der Hüllen der Milchfettkügelchen», durch die er 1912 den Doktorgrad errang, enthält eine moderne Auffassung über dieses auch heute noch zentrale Problem der Milchwissenschaft. Weiter sind zwei seiner grösseren Arbeiten zu 
nennen: "Studien über die Fettkügelchen der Kuhmilch", sowie "Studien über den Wassergehalt der finnischen Exportbutter." Bredenberg war lange Mitglied des finnischen Nationalkommittees der FIL und Ehrenmitglied des finnischen Milchwissenschaftlichen Vereines.

Neben seiner bahnbrechenden Tätigkeit an der Universität Helsinki wurde seine reiche Erfahrung und ein grosses fachliches Wissen aber auch im praktischen Leben gebraucht. Professor Bredenberg war sein ganzes Leben hindurch unermüdlich tätig um die Vieh- und Milchwirtschaft des Landes zu heben. Als Mitglied nahezu aller Vereine und Organisationen des Faches hat er noch bis in seine letzten Lebensjahre aktiv an der Qualitätsverbesserung der Milch und Molkereiprodukte mitgearbeitet, sowie mit regem Interesse die Entwicklung der Viehzucht verfolgt. Drei Generationen von Molkereifachleuten war er ein lebendiger Begriff und die meisten kannten und schätzten ihn persöhnlich. Aus dem ununterbrochenen Kontakt mit der praktischen Milchwirtschaft schöpfte Professor Bredenberg jedoch immer wieder Inspiration für seine Lehrertätigkeit, die er in fast patriarchalischer Weise betrieb. Diese kam besonders stark in dem Studentenverein Svenska Studenters Agro-forstförening zum Ausdruck, den Bredenberg gründete und bei dessen $\mathrm{Zu}$ sammenkünften er bis zum Jahre 1954 selten fehlte.

Es ist Bredenberg vergönnt gewesen, den Aufschwung der finnischen Milchwirtschaft von Anbeginn an mitzuerleben und sein Anteil an dieser Entwicklung ist nicht unerheblich gewesen. Hinter seinem Lebenswerk steht jedoch seine Persöhnlichkeit mit einem Reichtum an geistiger Vitalität und physischer Kraft, Herzensgüte und Humor, Eigenschaften die denen, die mit ihm in Kontakt kamen unvergesslich bleiben werden. 